LU Juan, LU Yan

\title{
Dimensions and influencing factors of customer loyalty in the intermittent service industry
}

(C) Higher Education Press and Springer-Verlag 2009

\begin{abstract}
This research empirically studies customer loyalty in the intermittent service industry with samples from the catering business in Beijing. Results show that customer loyalty in the intermittent service industry is composed of three causally related dimensions, namely cognitive loyalty, affective loyalty, and behavioral loyalty. Factors influencing customer loyalty in the intermittent service industry are customer satisfaction, service quality, and customer perceived value (CPV), in descending order of significance. These factors vary in their function mechanisms and effects on different dimensions of customer loyalty.
\end{abstract}

Keywords intermittent service industry, customer loyalty, influencing factors, empirical analysis

\begin{abstract}
摘要 以餐饮业为实证对象, 对间断性服务业的顾客忠诚问题进行专门的研究与讨 论。结果表明, 间断性服务业的顾客忠诚可用认知忠诚、情感忠诚和行为忠诚三个 维度来刻画, 且三个维度之间存在因果关系; 影响间断性服务业顾客忠诚的主要因 素以及影响程度从大到小依次是顾客满意、服务质量和感知价值; 各影响因素对顾 客忠诚各维度的影响机理与程度各不相同, 由此可得出提升顾客忠诚的若干管理启 示。
\end{abstract}

Translated and revised from Shuliang jingji jishu jingji yanjiu 数量经济技术经济研究 (The Journal of Quantitative \& Technical Economics), 2007, (3): 91-101

LU Juan $(\bowtie)$

College of Economics and Management, China Agricultural University, Beijing 100193, China

E-mail:lujuancau@163.com

LU Yan

College of Economics and Management, China Agricultural University, Beijing 100193, China

E-mail: twored_ly@163.com 


\section{Introduction}

It takes five times more expenses to attract a new customer than to retain an existing one. As time goes by, loyal customers will bring in more new customers through their repeat purchase, premium payment, and word-of-mouth (Reichheld and Sasser, 1990). These findings in customer loyalty research have increasingly attracted attention from scholars and practitioners alike. As we enter the age of service economy, competition in the service industry has intensified greatly. In comparison with other industries, service industry depends more on customer loyalty. As a result, more scholars have paid growing amount of attention to customer loyalty (also known as service loyalty).

Many scholars (e.g., Oliver, 1999; Zeithaml et al., 1996; Bloemer and Ruyter, 1998) have conducted useful exploration on the dimensions and influencing factors of service (customer) loyalty. Much of the research, however, was conducted by western researchers aimed at one or several specific service industries, and the conclusions were inconsistent. Others studied several typical service industries concurrently under certain standards, neglecting factors influencing negatively customer loyalty as they divided service industries into different subgroups.

We argue that a division of service industry into continuous and intermittent ones in accordance with the specific relationship between customers and service providers shall be beneficial to further studies on the issue of customer loyalty. Specifically, continuous service refers to those services in which service providers maintain long-term relationship with their customers, such as banking, insurance and telecommunication industries. In contrast, intermittent service refers to those services in which service providers only maintain short-termed interaction with their customers, such as catering, hotel or hairdressing businesses. Due to these differences in the nature of service, in comparison with continuous service industry, intermittent service industry tends to have more difficulties in maintaining long term relationship with its customers. Hence it is more urgent for researchers and practitioners to study customer loyalty in intermittent service industry considering that a majority of extent literature on customer loyalty focus on continuous service industries, such as banking, insurance and telecommunication (Lu et al., 2005).

This paper chooses a typical intermittent service industry - catering business as a sample to empirically study customer loyalty in the industry. We aim at answering the following questions: 1) What dimensions are included in customer loyalty of intermittent service industry? What are the interrelationships among these 
dimensions? 2) What are the factors and their mechanisms influencing customer loyalty in intermittent service industry? 3) What are the differences among factors affecting each dimension of customer loyalty in intermittent service industry?

\section{Research hypotheses and model construction}

\subsection{Customer loyalty in service industry and its dimensions}

Customer loyalty in the service industry, also known as service loyalty, refers to customers' adherence to certain brands in the service industry. As a rule, the degree of customer loyalty to certain service companies varies with the services they accept, embodied as a series of different purchase attitudes or behaviors in market. Researchers thus can measure customers' loyalty to a certain service company by surveying these different purchase attitudes or behaviors. However, as scholars' understanding of customer loyalty varies greatly, there have been a plethora of opinions on customer loyalty measurement, such as the behavior approach, affection approach, behavior-affection approach, cognition-affection-behavior approach, and cognition-affection-conation-behavior approach.

More specifically, scholars holding the behavior approach (e.g., Tucker, 1964) contend that customer loyalty to a brand is manifested as repeat purchase behaviors, affection approach advocates argue that purchase behavior can not distinguish real loyalty from fake ones and what matters here is the emotional bond between customers and the service-providing firms. Jones and Sasser (1995) defined customer loyalty as "a sense of belonging or affection that customers hold toward certain firm's staff, products, or services." Behavior-affection approach supporters point out that customer loyalty can be measured by comprehensively investigating customers' repeat purchase behaviors and their emotional preference to a firm.

The cognition-affection-behavior approach (e.g., Lu et al., 2001) points out that customer loyalty should be measured simultaneously from the three levels of customer cognition, affection and behaviors. Adding a new dimension of conation, the advocates of cognition-affection-conation-behavior approach (e.g., Oliver, 1999) believe that customer loyalty consists of cognitive loyalty, affective loyalty, conative loyalty and behavioral loyalty, which is by far the most comprehensive depiction of customer loyalty. However, as it is difficult to distinguish between customer affection dimension and conation dimension in practical measurement, we thus adopt the three dimension model of "cognition-affection-behavior" for its operationability. Thus we propose the following hypothesis:

H1 Customer loyalty in service industry has a multi-dimensional structure 
consisting of cognitive loyalty, affective loyalty and behavior loyalty.

\subsection{Influencing factors of customer loyalty in service industry}

Influencing factors of customer loyalty have long been core issues of studies on customer issue. Researchers both at home and abroad have conducted extensive studies on this issue. Prior literature regarded service quality as the key influencing factor or even the only determinant of customer loyalty. As time goes by, some scholars have found out that mere improvement of service quality while neglecting the impacts of price and other elements on customer choice can not continuously retain customer loyalty. Accordingly, these scholars pointed out that the perceived value of what customers give and receive had stronger explanation power for customer loyalty. Still, other scholars assumed the importance of customer satisfaction by pointing out that customer satisfaction was the precondition of customer loyalty. Later studies have proved that customer satisfaction was a necessary but not a sufficient condition for customer loyalty. At present, it is generally accepted that service quality, CPV and customer satisfaction consist of the three most important influencing factors of customer loyalty.

Service quality is subject to customer perception, which is a result of customer's comparison of service expected with the actual service they receive. The positive affect of service quality on customer loyalty has been supported by a wide array of research (e.g., Zeithaml, 1996). Cronin et al. (2000) found that the impact of service quality on customer loyalty was far greater than we expected for it not only directly affected customers' behavior intentions, but also influenced purchase intention via service value and customer satisfaction. In addition, these impacts are of continuous and significant quality. Bai (2002) also pointed out that even though service quality might not be the only reason to retain customers, it surely had some critical impact on customer loyalty improvement. Thus we develop the second hypothesis:

H2 Service quality is directly and positively related to customer loyalty in service industry.

CPV is customers' subjective comparison of overall gains with overall payments. The social exchange theory holds that under the restriction of limited search cost, product or service knowledge and levels of income, customers are rational seekers of "maximized values". Blackwell et al. (1999) confirmed that perceived value was the determinant of customers' repeat purchase intentions. We thus propose the next hypothesis:

H3 $C P V$ is directly and positively related to customer loyalty in service industry.

Customer satisfaction refers to the emotion of happiness or disappointment a customer feels after he/she compares the perceived effects (or results) of a certain 
product with the effects he/she expects. Customer satisfaction is one of the earliest factors used to explain customer loyalty for people tend to believe that there is a significant and positive relationship between customer satisfaction and brand loyalty. That is to say, the higher the customer satisfaction, the stronger the possibilities of repeat purchase. In other words, if customers are happy with their purchase experiences with a particular service firm, they will then surely remain loyal to this firm. The discovery of "customer satisfaction trap" has promoted researchers to conduct more and deeper studies on the issue. The extant literature has shown that customer satisfaction is a necessary condition rather than a sufficient condition for customer loyalty (Oliver, 1999). There is only a weak relationship between customer satisfaction and loyalty. Later research also revealed a non-linear relationship between the two. Some researchers even argued that there was no significant relationship between the two at all. Yet an analysis of the extant literature shows that a vast majority of scholars still hold that customer satisfaction positively affects customer loyalty, hence Hypothesis 4 is developed.

H4 Customer satisfaction directly and positively affects customer loyalty in service industry.

Besides directly affecting customer loyalty, does the interrelationship among service quality, CPV and customer satisfaction also indirectly affect customer loyalty? No consistent conclusion has been reached so far. Large amount of empirical research (Dick and Basu, 1994) has approved that service quality was the antecedent for customer satisfaction. According to Oliver, service quality remains an important driver for customer satisfaction, despite that customer satisfaction is measured based on any single purchase behavior or accumulated shopping experiences over time. Ruyter and Peeters (1998) studied samples in banking industry and found that except direct influence, service quality also indirectly influenced customer loyalty through the moderation of customer satisfaction. As a matter of fact, judging from the connotations of quality and satisfaction, the latter means a post-consumption experience after comparing perceived product/service quality with expected one. Thus service quality is an antecedent for customer satisfaction, not the opposite.

H5 Service quality has a direct and positive impact on customer satisfaction.

$\mathrm{CPV}$ is a customer's judgment of service quality in relation to the price of the service. Thus service quality directly determines values of a service perceived by customers.

H6 Service quality has a direct and positive impact on $C P V$.

Extant literature on service management has shown that customer satisfaction is a result of CPV. Cronin et al. (2000) found that CPV directly affected customers' brand loyalty behaviors. Meanwhile, it also indirectly promoted customer loyalty. Hence, we propose hypothesis 7 : 
H7 CPV directly and positively affects customer satisfaction.

In general, service quality affects customer loyalty directly and indirectly (through the mediation of $\mathrm{CPV}$ and customer satisfaction). While directly affecting customer loyalty, CPV also indirectly influences customer loyalty via customer satisfaction. The degree of customer satisfaction finally decides the form of customer loyalty. Thus we establish a conceptual model of the influencing factors of customer loyalty in service industry as follows:

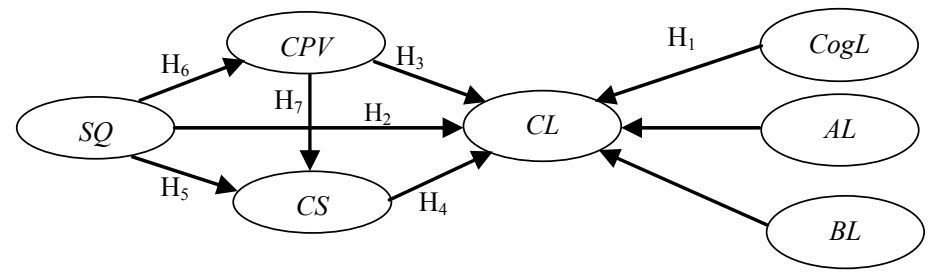

Fig. 1 Conceptual model M1

Note: Abbreviations $S Q, C P V, C S, C L, \operatorname{Cog} L, A L, B L$ stand for service quality, customer perceived value, customer satisfaction, customer loyalty, cognitive loyalty, affective loyalty and behavior loyalty, respectively.

\section{Data collection and variable measurement}

\subsection{Data collection}

Due to full competition, high freedom of customer choice, and high frequency of customer consumption behaviors in the catering industry, we chose it as the sample industry in this study. At the beginning, street intercept survey and restaurant on-the-pot survey were adopted for a small-scale pretest. Data collected from this pretest were used to modify the items and wording in the original questionnaire. Formal survey was conducted between February and March in 2006 and the methods of convenience sampling and quota sampling were used. When we strictly control survey respondents and process, quota sample can get very similar results to those of probability sampling (McDaniel, 2002). Control variables include customer age, gender, income, education and occupation (data obtained from Beijing Statistical Yearbook 2003). 393 valid questionnaires were obtained out of a total of 500 copies delivered (with a return rate of valid copies $78.6 \%$ ).

\section{2 Variable measurement}

(1) Service quality. The SERVQUAL Scale developed by Parasuraman et al. 
(1998) was used to measure service quality. Minor changes were made to the original scale to make it more suitable for the catering industry in terms of tangibility, reliability, responsiveness, guarantee and empathy.

(2) CPV. The measurement of CPV is conducted in terms of the following three aspects. i.e. "food and service in this restaurant are very good", "the price here is reasonable in comparison with other restaurants", "worthwhile consumption here".

(3) Customer satisfaction. Drawing on relevant studies conducted by Han (2003) and Cronin et al. (2000), we measured customer satisfaction here in terms of "satisfaction of food and service", "pleasant dining experience", and "commitment to one's own choice".

(4) Customer loyalty. Scholars vary greatly in their measurement of customer loyalty. Dick and Base (1994) found that customers were keen to spread the good reputation of a certain brand among his/her friends. Thus many researchers used recommendation as an important index for customer loyalty (Zeithaml, 1996). Researchers also found out in later studies that highly loyal customers tended to select their favorite brand as their No. 1 choice. Reichheld and Sasser (1990) discovered that in comparison with disloyal ones, loyal customers had lower level of price flexibility. Consistent with this conclusion, Dick and Base's (1994) study revealed that highly loyal customers usually demonstrated a decrease in motive for new brand searching, resulting in giving up of choosing other brands and reduced effort in the process of decision making.

Research has proved that agreeable consumption experience and accumulated trust will give rise to a strong intention of repeat purchase behaviors among loyal customers. In addition, owing to the diffusion effect of trust in certain firms, customers tend to reduce their perceived risks in purchasing other services provided by the same firm, thus leading to increase in repeat purchase of the same brand. Another important feature of loyal customer is that they always frequently and stably purchase their favorite service or products. Some scholars highlighted the cognitive dimension of customer loyalty (Oliver, 1999; Han et al., 2003), which was defined as beliefs customers hold about the superior quality of certain brands to other brands. As such, we argue that brand recognition, reputation, corporate social responsibilities, and public image can be used to measure customer cognitive loyalty. Thus we used ten indexes (i.e. brand recognition, brand reputation, corporate social responsibilities, corporate public image, recommendation, word-of-mouth, first choice, repeat purchase intention, cross-purchase behaviors, tolerance), consisting of 12 questions (among them, the index of cross-purchase behavior includes two items of "purchase more" and "try their new services"; the index of "tolerance" includes two items of "tolerance for increase in price" and "boycott and turn to other firms"). A seven-point Likert scale was adopted with anchor points ranging from "totally 
agree" to "totally disagree".

\section{Data analysis}

\subsection{Credibility and validity test}

Cronbach $\alpha$ for the four latent variables, i.e. service quality, CPV, customer satisfaction, and customer loyalty, are $0.92,0.87,0.90$ and 0.87 , respectively. All of them are bigger than the critical value of 0.7 (Nunnally, 1978), showing a good credibility of the scales adopted in this article.

Data validity consists of content and construct validity. Since all the items in the questionnaires we used were adopted from extant literature, a good content validity is guaranteed. Construct validity includes convergent validity and discriminant validity. Lisrel 8.7 software package was used to include all four latent variables into the same model to do an exploratory factor analysis (EFA). Results demonstrated that high goodness-of-fit: NFI, NNFI, CFI, GFI, and AGFI are 0.98, 0.97, 0.99, 0.96 and 0.90 , respectively. $\chi^{2}$ equals 64.27 (degree of freedom=14). Factor loadings for all indexes on separately measured concepts are highly significant ( $T$ value falls from 14.14 to $21.72, p$ value $=0.00$ ). In addition, variances explained by each variable are all bigger than the co-variances among these variables. Taken together, the above statistics show that our data has pretty high convergent and discriminant validities.

\subsection{Analysis of the different dimensions of customer loyalty}

As for the measurement of customer loyalty dimensions, we divided the total sample into two sub-groups $\left(n_{1}=196, n_{2}=197\right)$ and used EFA (exploratory factor analysis) and CFA (confirmatory factor analysis) to analyze them, respectively.

Principal component analysis was used to extract common factors from the above 10 customer loyalty items. In addition, the varimax rotation was used for optimization of the data. As shown in Table 1, the 10 indexes (a total of 12 item questions) can be divided into three factors, with the loading of each correspondent factor bigger than 0.45 . Total variances explained by these factors amounted to $62.72 \%$. Specifically, brand recognition, reputation, corporate social responsibilities, and public image consist of factor 1 for they reflect more or less customers' cognition level and preference, hence the name cognitive loyalty. Recommendation, word-of-mouth, first choice, intention of repeat purchase, and cross-purchase behaviors constitute factor 2 for they reflect customers' emotional 
preference, hence the name affective loyalty. Price tolerance and willingness-to-wait constitute factor 3 for their reflection of customers' increase in tolerance as their preference grows for certain firms. We believe these behaviors are the embodiment of customer behavioral loyalty, hence the name of factor 3 is behavioral loyalty.

Table 1 Factor analysis of customer loyalty

\begin{tabular}{|c|c|c|c|c|c|c|c|}
\hline \multirow[t]{2}{*}{ Index } & \multicolumn{3}{|c|}{$\begin{array}{l}\text { Factor loadings in } \\
\text { exploratory factor analysis }\end{array}$} & \multicolumn{3}{|c|}{$\begin{array}{c}\text { Confirmatory factor } \\
\text { analysis }\end{array}$} & \multirow[t]{2}{*}{ Cronbach's $\alpha$} \\
\hline & Factor 1 & Factor 2 & Factor 3 & Factor 1 & Factor 2 & Factor 3 & \\
\hline Brand recognition & 0.47 & & & 0.60 & & & \multirow{4}{*}{0.73} \\
\hline Brand reputation & 0.72 & & & 0.79 & & & \\
\hline Social responsibilities & 0.80 & & & 0.75 & & & \\
\hline Public image & 0.77 & & & 0.79 & & & \\
\hline Recommendation & & 0.61 & & & 0.80 & & \multirow{6}{*}{0.86} \\
\hline Word-of-mouth & & 0.80 & & & 0.82 & & \\
\hline First choice & & 0.64 & & & 0.73 & & \\
\hline Repeat purchase intention & & 0.83 & & & 0.78 & & \\
\hline Cross-purchase & & 0.74 & & & 0.74 & & \\
\hline behavior & & 0.61 & & & 0.68 & & \\
\hline \multirow{2}{*}{ Tolerance } & & & 0.76 & & & 0.80 & \multirow{2}{*}{0.71} \\
\hline & & & 0.85 & & & 0.80 & \\
\hline $\begin{array}{l}\text { Goodness-of-fit for CFA: } \\
\text { CFI }=0.95, \text { IFI }=0.95, \mathrm{GF}\end{array}$ & $\begin{array}{l}\chi^{2}=183.9 \\
I=0.86\end{array}$ & $5, d_{.} .=51$, & $\chi^{2} / d . f .=3$. & $57, \mathrm{RMS}$ & $\mathrm{EA}=0.11$, & $\mathrm{NFI}=0.93$ & $3, \mathrm{NNFI}=0.94$, \\
\hline
\end{tabular}

CFA for sample 2 was conducted. As shown in Table 1, coefficients for factor corresponding to each items in the questionnaire are all significantly high. The model shows a good overall goodness-of-fit: Excepts the value of RMSEA a bit higher than the critical value of 0.1 , all other indexes fall with the required range $\left(\chi^{2} /\right.$ d.f. $=3.57<0.5$, NFI, NNFI, CFI all bigger than 0.9). Thus CFA result demonstrates a three-dimensional structure of customer loyalty and supports H1, i.e. customer loyalty in service industry is multi-dimensional, consisting of cognitive loyalty, affective loyalty and behavior loyalty.

4.3 Influencing factors of customer loyalty in service industry

To identify influencing factors of customer loyalty in service industry, we used customer loyalty as the population variance and constructed a structural equation 
model (M2) ${ }^{1}$ for the interrelation among customer loyalty, service quality, $C P V$, customer satisfaction as follows:

$$
\begin{aligned}
& \operatorname{CPV}\left(\eta_{1}\right)=\gamma_{11} S Q\left(\xi_{1}\right)+\zeta_{1} \\
& C S\left(\eta_{2}\right)=\beta_{21} \operatorname{CPV}\left(\eta_{1}\right)+\gamma_{21} S Q\left(\xi_{1}\right)+\zeta_{2} \\
& C L\left(\eta_{3}\right)=\beta_{32} \operatorname{CS}\left(\eta_{2}\right)+\beta_{31} C P V\left(\eta_{1}\right)+\gamma_{31} S Q\left(\xi_{1}\right)+\zeta_{3}
\end{aligned}
$$

The maximum likelihood method in Liseral 8.7 software package is used to test M2. As shown in Fig. $2, \chi^{2}=290.83, p=0.0$. Considering $p$ value's extreme sensitivity to the number of samples, other indexes are more important to a large-sample model. In M2, $\chi^{2} / d . f .=4.10$ (smaller than the critical value of 5). Except that RMSEA is slightly higher than 0.08, NFI, NNFI, CFI and other Goodness-of-fit indexes are all above 0.9, indicating M2 has an excellent overall fitness.

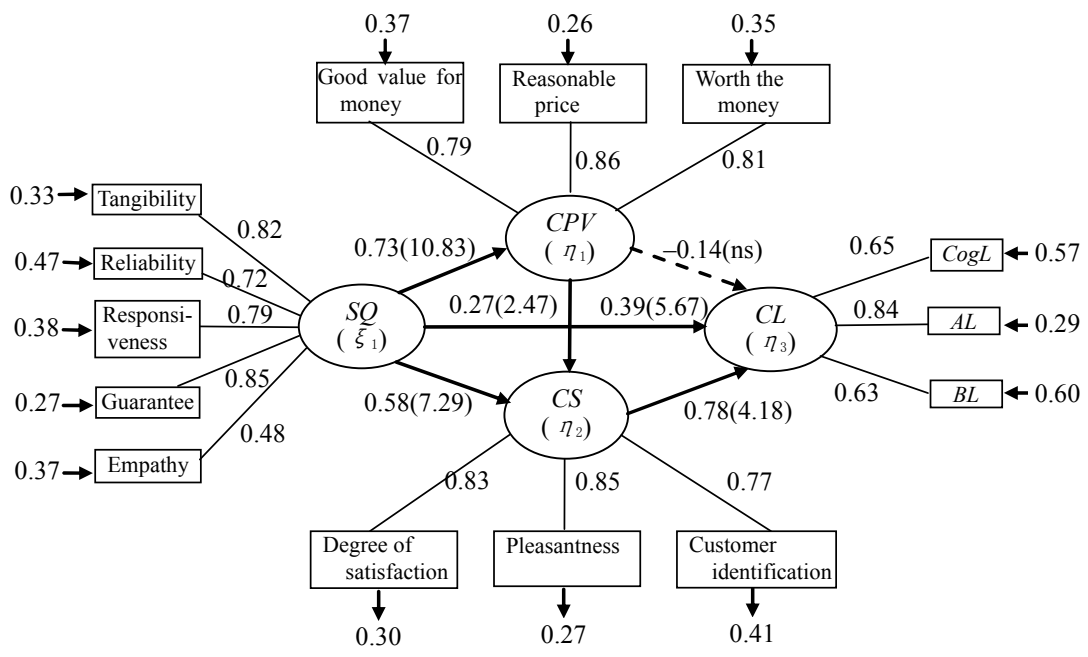

$\chi^{2}=290.83(\mathrm{P}=0.0)$, d.f. $=71, \chi^{2} /$ d.f. $=4.10, \mathrm{RMSEA}=0.089, \mathrm{RMR}=0.084$, $\mathrm{NFI}=0.97, \mathrm{NNFI}=0.97, \mathrm{CFI}=0.97, \mathrm{IFI}=0.97, \mathrm{GFI}=0.90, \mathrm{AGFI}=0.86$

Fig. 2 Testing results of M2

Note: All path coefficients in the model are standardized. Numbers in the parentheses are the $t$ values for path coefficients. The same in Fig. 3.

$1 \xi_{i}$ stands for exogenous latent variable, $\eta_{i}$ stands for endogenous latent variable, $\gamma_{i j}$ is the effects of exogenous latent variable $\xi_{i}$ on endogenous latent variable $\eta_{i}, \beta_{i j}$ is the effects of endogenous latent variable $\eta_{j}$ on endogenous latent variable $\eta_{i}, \zeta_{i}$ is the estimated residual.The same in structural equation model M3. 
Among the influencing factors of customer loyalty, all the path coefficients pass the significance testing except $C P V(\beta=-0.14, t=-1.48)$. In other words, $C P V$ does not have a direct and positive effect on customer loyalty, failing to support H3. Service quality and customer satisfaction directly and positively affect customer loyalty, explaining as much as $82 \%$ of the total variance. Thus both $\mathrm{H} 2$ and $\mathrm{H} 4$ are supported. Service quality $(\gamma=0.58, t=7.29)$ and $C P V(\beta=0.39$, $t=5.67)$ have positive and direct effects on customer satisfaction, explaining as much as $83 \%$ of the total variance. The results also show that service quality has a slightly bigger impact on customer satisfaction than that of $C P V$, thus supporting $\mathrm{H} 5$ and $\mathrm{H} 7$. In addition, the effect of service quality on $C P V(\gamma=0.73$, $t=10.83$ ) is also confirmed (explaining as much as $53 \%$ of the total variance), thus supporting $\mathrm{H} 6$.

4.4 Analysis of the respective effects of each influencing factor on dimensions of customer loyalty

As above, service quality and customer satisfaction directly affect customer loyalty. $C P V$ does not impact customer loyalty directly but via the indirect moderation of customer satisfaction. However, do service quality and customer satisfaction directly improve customer satisfaction at different levels? How do the above influencing factors respectively affect different dimensions of customer loyalty? Are there any interrelationships among different dimensions of customer loyalty? We construct another structural equation model (M3) as follows, in which we presume service quality and customer satisfaction exert significant and direct influence on all the three dimensions of customer loyalty (i.e. cognitive loyalty, affective loyalty and behavior loyalty). According to the attitude theory in consumer behavior studies, a certain customer behavior has four stages of cognition, affection, conation and behavior before they purchase certain products or services and the earlier stages during this process will positively affect the later stages. Hence, we propose that cognitive loyalty exerts positive and direct impacts on both affective and behavior loyalties, and direct impacts of affective loyalty on behavioral loyalty.

$$
\begin{aligned}
& C P V\left(\eta_{1}\right)=\gamma_{11} \operatorname{SQ}\left(\xi_{1}\right)+\zeta_{1} \\
& C S\left(\eta_{2}\right)=\beta_{21} \operatorname{CPV}\left(\eta_{1}\right)+\gamma_{21} \operatorname{SQ}\left(\xi_{1}\right)+\zeta_{2} \\
& \operatorname{Cog} L\left(\eta_{3}\right)=\beta_{32} \operatorname{CS}\left(\eta_{2}\right)+\gamma_{31} \operatorname{SQ}\left(\xi_{1}\right)+\zeta_{3} \\
& A L\left(\eta_{4}\right)=\beta_{42} C S\left(\eta_{2}\right)+\beta_{43} \operatorname{Cog} L\left(\eta_{3}\right)+\gamma_{41} \operatorname{SQ}\left(\xi_{1}\right)+\zeta_{4} \\
& B L\left(\eta_{5}\right)=C S\left(\eta_{2}\right)+\operatorname{Cog} L\left(\eta_{3}\right)+A L\left(\eta_{4}\right)+\operatorname{SQ}\left(\xi_{1}\right)+\zeta_{5}
\end{aligned}
$$


As shown in Fig. 3, the overall fitness of M3 is consistent with Hair et al.'s (1995) standards. The results support that service quality has a positive and direct influence on the cognitive and behavioral dimensions of customer loyalty, while its influence on the affective dimension is not statistically significant. Customer satisfaction has direct, positive and significant impacts on the affective and behavioral loyalties (rather than cognitive loyalty). Our results also reveal a linear causal relationship among the three dimensions of customer loyalty, that is to say, cognitive loyalty improves affective loyalty and affective loyalty improves behavioral loyalty. But we do not find a direct impact from cognitive loyalty on behavioral loyalty.

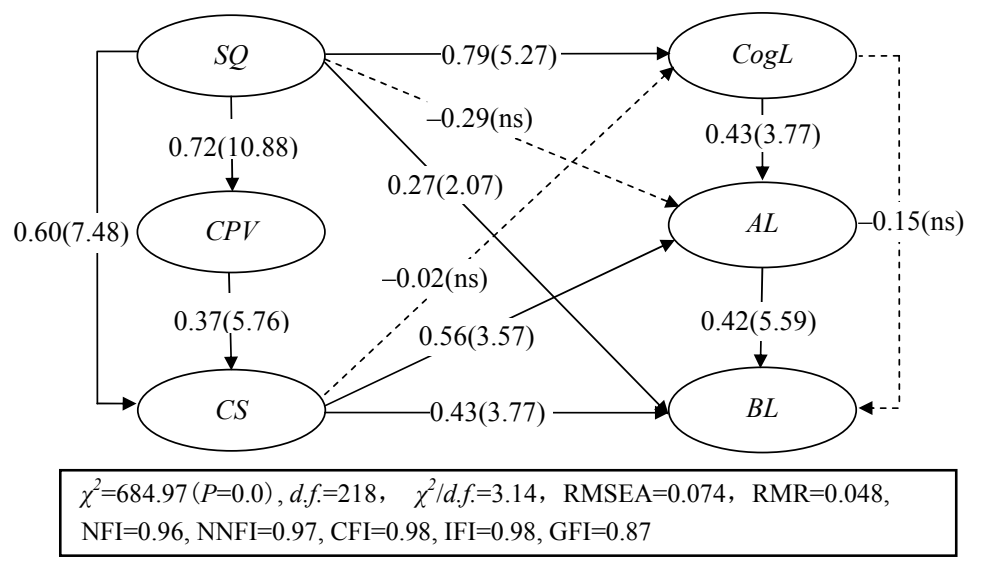

Fig. 3 Testing results of M3

To further explore the different impacts of the above influencing factors on specific dimension of customer loyalty, we adopted the weighted analysis method to calculate the total effects of influencing factors on all dimensions of customer loyalty. As shown in Table 2, service quality is the only factor influencing cognitive loyalty (standardized path coefficient=0.79). Some scholars have already pointed out that customer cognition originates form word-of-mouth, firm's advertising and previous shopping experience with the firm. Our results further show that service quality is the most important factor influencing customer's cognitive preference. Factors influencing affective loyalty are, in descending order of significance, customer satisfaction (0.56), cognitive loyalty (0.43), $C P V(0.21)$, and service quality (0.15). Factors influencing behavioral loyalty are: service quality $(0.64)$, customer satisfaction (0.43), affective loyalty (0.42), cognitive loyalty $(0.24)$ and $C P V$ (0.16). 
Table 2 Analysis of the effects of different influential factors on dimensions of customer loyalty

\begin{tabular}{lccc}
\hline \multirow{2}{*}{ Path } & \multicolumn{3}{c}{ Path effects } \\
\cline { 2 - 4 } & Direct effects & Indirect effects & Total effects \\
\hline$S Q \rightarrow$ ConL & 0.79 & - & 0.79 \\
$C P V \rightarrow$ Con $L$ & - & - & - \\
$C S \rightarrow$ ConL & - & - & 0.43 \\
$S Q \rightarrow A L$ & - & 0.15 & 0.15 \\
$C P V \rightarrow A L$ & - & 0.21 & 0.21 \\
$C S \rightarrow A L$ & 0.56 & & 0.56 \\
$C o n L \rightarrow A L$ & 0.43 & - & 0.43 \\
$S Q \rightarrow B L$ & 0.27 & 0.37 & 0.64 \\
$C P V \rightarrow B L$ & - & - & 0.16 \\
$C S \rightarrow B L$ & 0.43 & 0.24 & 0.43 \\
$C o n L \rightarrow B L$ & - & - & 0.24 \\
$A L \rightarrow B L$ & 0.42 & & 0.42 \\
\hline
\end{tabular}

\section{Conclusions and implementations}

Based on a review of relevant literature on the evaluation models and influencing factors of customer loyalty, this paper proposes a conceptual model and research hypotheses in terms of the external embodiment and internal function mechanism of customer loyalty. Using the catering industry in Beijing as an example, we empirically get the following conclusions.

(1) Customer loyalty in service industry consists of three causally related dimensions, namely cognitive, affective and behavioral loyalties. By measuring these dimensions of customer loyalty, firms in the service industry can measure and determine the specific dimension and stage of customer loyalty so as to make effective and well-directed marketing plans to boost their customers' behavioral loyalty and increase profit.

(2) Cognitive loyalty is the foundation of formation of affective and behavioral loyalties. It is affected by a firm's brand recognition, reputation, social responsibilities and public image. Thus firms in the intermittent service industry need to establish good pubic image, spread their brand recognition and reputation and fulfill their corporate social responsibilities in an effort to cultivate a higher level of customer loyalty.

(3) Main factors influencing customer loyalty in the intermittent service industry are, in descending order of significance, customer satisfaction, service quality and $C P V$. Among them, $C P V$ does not affect customer loyalty directly 
but through the moderation of customer satisfaction. It shows that in intermittent service industry, reasonable price alone is not enough to boost customer loyalty, which increases only after the service value perceived by customer transfers into pleasant shopping experience. Our results also show that service quality exerts smaller direct impact on customer loyalty than that of customer satisfaction, which is inconsistent with the conclusion that service quality in continuous service industry does not affect directly customer loyalty ( $\mathrm{Lu}$ et al., 2005). We can thus infer that intermittent service industry (particularly the catering industry) shall not ignore service quality in their effort to improve customer loyalty for customers are likely to become your customer of long standing (loyal customers) simply because of the high quality service they enjoyed in one firm. Besides significantly promoting customer loyalty, customer satisfaction also functions as the moderator for service quality and $C P V$. We can come to the conclusion that customer satisfaction is the real determinant of customer loyalty in intermittent service industry. Pleasant experience and recognition of quality service can only be transferred into customer loyalty only after customers are satisfied. This finding is of great practical significance to practitioners and managers in intermittent service industry in that it shows the importance of customer-satisfaction-orientation. Firms in intermittent service industry shall not subjectively determine the approaches and degrees of service quality improvement for their customers. In other words, service design and delivery shall be able to meet customers' needs (including those subtle ones).

(4) Different influencing factors' impacts on the dimensions of customer loyalty vary in degree and function mechanisms. Among them, service quality is the only influencing factor of cognitive loyalty. Factors influencing affective loyalty are, in descending order of significance, customer satisfaction, cognitive loyalty, $C P V$, and service quality. Factors influencing behavioral loyalty are: service quality, customer satisfaction, affective loyalty, cognitive loyalty and $C P V$. These findings show that, in comparison with continuous service industry, customer cognitive and behavioral loyalties in intermittent service industry rely more on service quality, which reminds once again managers in the industry to pay close attention to service quality. Meanwhile, we find out customer satisfaction is the real determinant of customer loyalty in that it exerts direct and significant impacts on both affective loyalty and behavioral loyalty. Thus firms in the intermittent industry can only improve customer loyalty by means of improving customer satisfaction.

\section{Limitations and future direction}

Based on samples from catering industry in Beijing, this paper empirically 
explores the dimensions and influencing factors of customer loyalty in the intermittent industry. Some limitations include:

(1) We discuss only the impacts of service quality, $C P V$ and customer satisfaction on customer loyalty. There are many other potential influencing factors of customer loyalty, such as the psychological characteristics of customer risk perception, demographical characteristics (e.g., income, gender, etc), degree of competition in service industry, customer trust and sense of belongings. To gain deeper understandings of these factors' impact on customer loyalty, we need to include them all in a model to conduct a more comprehensive analysis in future studies.

(2) Loyalty is a comprehensive variable consisting of cognitive, attitude and behavioral factors. Due to the difficulty in obtaining customer behavioral data, scholars usually use behavioral intention as a substitute of real actions. We adopt customers' "price tolerance" and "willing to wait longer" as substitute variables for behavioral loyalty, which avoid the variance between behavioral intention and real actions to a certain degree. However, these two substitutes can not completely represent customer's real purchase behaviors. Thus, the accuracy of our conclusions is affected. Future studies need to collect continuous data (such as the frequency of repeat purchase, wallet share, etc.) to improve the accuracy of research conclusions.

Acknowledgements This work is supported by the National Science Foundation of China (No. 70372029) and the Humanities and Social Science Project of the Ministry of Education (No. 03JD630006).

\section{References}

Bloemer J, De Ruyter K, Peeters P (1998). Investigating drivers of bank loyalty: The complex relationship between image, service quality and satisfaction. International Journal of Bank Marketing, 16: 276-286

Cronin Jr J, Brady M, Hult G (2000). Assessing the effects of quality, value, and customer satisfaction on consumer behavioral intentions in service environments. Journal of Retailing, 76: $193-216$

Dick A, Basu K (1994). Customer loyalty: Toward an integrated conceptual framework. Journal of the Academy of Marketing Science, 122: 99-113

Jones O T, Sasser W E (1995). Why satisfied customers defect. Harvard Business Review, 73(6): 88

Lu T P, Tang P Y (2001). An integrated model of service loyalty. Academy of Business and Administrative Sciences International Conferences

McDaniel C, Gates R (2002). 市场调研精要 (Marketing Research Essentials), 范秀成（译)

(Fan Xiucheng (trans.)). 北京: 电子工业出版社

Nunnally J (1978). Psychometric Theory. New York: McGraw-Hill

Oliver R L (1999). Whence consumer loyalty? Journal of Marketing, 63: 33-44 
Parasuraman A, Zeithaml V, Berry L (1988). SERVQUAL: A multiple-item scale for measuring consumer perceptions of service quality. Journal of Retailing, 64: 1240

Reichheld F F, Sasser W E (1990). Zero defections: Quality comes to services. Harvard Business Review, 68(5): 105

Tucker W (1964). The development of brand loyalty. Journal of Marketing Research, (1): 32-35

Zeithaml V, Berry L, Parasuraman A (1996). The behavioral consequences of service Quality. Journal of Marketing, 60: 31-46

白长虹, 刘炽 (Bai Changhong, Liu Chi) (2002). 服务企业的顾客忠诚及其决定因素研究 (Customer loyalty and its determinants for service firms). 南开管理评论, (6)

韩晓芸, 汪纯孝 (Han Xiaoyun, Wang Chunxiao) (2003). 服务性企业顾客满意感与忠诚感关系 (Relationship Between Customer Satisfaction and Loyalty in Service Industry). 北京: 清华大 学出版社

陆娟, 芦艳, 娄迎春 (Lu Juan, Lu Yan, Lou Yingchun) (2006). 服务忠诚及其驱动因素：基于银 行业的实证研究 (Service loyalty and its influencing factors: An empirical study based on the banking industry). 管理世界, (8) 